\title{
Effect of Presurgical Nasoalveolar Molding in Unilateral Cleft Lip and Palate Infants
}

\author{
Jin-Sun Kim, Young-Jin Kim, Soon-Hyeun Nam, Hyun-Jung Kim \\ Department of Pediatric Dentistry, School of Dentistry, Kyungpook National University
}

\begin{abstract}
Cleft lip and palate, the most common craniofacial anomalies, are severe congenital defects that have an incidence of 0.28 to 3.74 per 1000 live births. Although there has been great improvement in the field of cleft surgery, surgical approach cannot be the single solution to resolve the various problems encountered in patients with cleft lip and palate. The concept of presurgical infant orthopedics (PSIO) for gradual closure of the cleft gap and simplified surgical performance was first introduced by McNeil in 1950. Recently, there are many attempts not only to approximate the alveolar segments but also to reshape the nasal cartilage.

Three infants with unilateral cleft lip and palate were referred from the department of Plastic Surgery for presurgical nasoalveolar molding (PNAM). Maxillary appliances using resin with orthodontic wire were fabricated. Then these appliance was applied until patients underwent lip surgery. In all cases, the patients could wear the appliance all day since they were able to eat even with the appliance on, This resulted in significant improvements in the nasal symmetry were found. Our appliance, namely K-NAM, extends the wearing time within the limited period and as a result it is expected to maximize the treatment effects. Used properly, this appliance would play a major role in enhancing nasal symmetry with satisfactory results.
\end{abstract}

Key words : Presurgical nasoalveolar molding (PNAM), Unilateral cleft lip and palate

\section{Introduction}

Cleft lip and palate (CLP), one of the most common facial deformities, are severe congenital anomalies with a global incidence of 0.28 to 3.74 per 1000 live births. Many of these congenital anomalies are genetically determined, although in most cases, the cause is unknown or under teratogenic influences ${ }^{11}$.

CLP can generally be divided into unilateral and bilateral types. In bilateral CLP, protrusion of the premaxilla and deficient columella have been the main obstacles in achieving satisfactory treatment results. Patients with unilateral CLP are characterized by nasal asymmetry due to a shortened columella on the cleft side that deflects the nose to the unaffected side. The alar base is displaced laterally, inferiorly, and posteriorly, resulting in flat, elongated ala having an S-shaped curve on the cleft side. Furthermore, the tip of the nostril becomes asymmetric and displaced downward on the cleft side ${ }^{2-4}$.

Despite many protocols for treating CLP patients, surgical repair alone cannot resolve the multiple problems confronting CLP. The management of CLP patients should be approached as a multidisciplinary team to achieve the optimal result. The basic treatment objective

Corresponding author : Hyun-Jung Kim

Department of Pediatric Dentistry, School of Dentistry, Kyungpook National University, 2177 Dalgubeol-daero, Jung-gu, Daegu, 700-412, Korea

Tel: +82-53-600-7211 / Fax: +82-53-426-6608 / E-mail: jungkim@knu.ac.kr

Received January 23, 2013 / Revised July 5, 2013 / Accepted July 24, 2013

※ This research was supported by Kyungpook National University Research Fund, 2013. 
is to restore normal anatomy including the nasal components as well. Hence, presurgical molding is required.

According to Matuo and Hirose ${ }^{5,6)}$, a high level of hyaluronic acid, a component of proteoglycan constructing cartilage, accounts for the high plasticity of neonatal cartilage. Since maternal estrogen induces a high level of hyaluronic acid, plasticity of nasal cartilage is fair immediately after birth, and after about 6 weeks, the acid level is gradually reduced resulting in the decreased cartilage plasticity. Therefore the molding of nasal cartilage and surrounding soft tissues is most effective within 3 to 4 months after birth.

Modern presurgical infant orthopedics (PSIO) was started by $\mathrm{McNeil}^{7}$ in 1950, and has been used for more than 60 years. By using a series of resin plates, he was able to mold the alveolar segments into the desired position. In 1975, Georgiade and Latham ${ }^{8)}$ presented a pinretained active appliance which retract the premaxilla and expand the posterior alveolar segments at the same time. Later in 1987, Hotz ${ }^{9}$ invented an appliance with a passive orthopedic plate for delayed alignment of the cleft segments. In addition, PSIO technique has the merits of normal positioning of the tongue and enabling feeding. But these techniques intend to mold the alveolar segments only and are not concerned with deformity of the nasal part. Thus a novel idea and technique for nasoalveolar molding is in demand.

Matsuo ${ }^{6)}$ was the first researcher who described presurgical molding of the nasal cartilage in cleft neonates. Grayson et al. ${ }^{10)}$ described the first presurgical nasoalveolar molding (PNAM) appliance, a new approach to the traditional method of PSIO for patients with unilateral and bilateral clefts.

These procedures were achieved with acrylic resin plates and nasal stents to mold the alveolar process and nasal cartilage into normal form and position.

The goal of our appliance, namely K-NAM (KNasoalveolar Molding), is to facilitate the fitting and maximize the benefits of PNAM which improves nasal symmetry by elongating the columella and reshaping the nasal cartilage. This report aims to introduce K-NAM appliance and to discuss the result of K-NAM treatment.

\section{Case Report}

Three infants were referred from the department of Plastic Surgery, Kyungpook National University Hospital with their dental stone models. The patients,

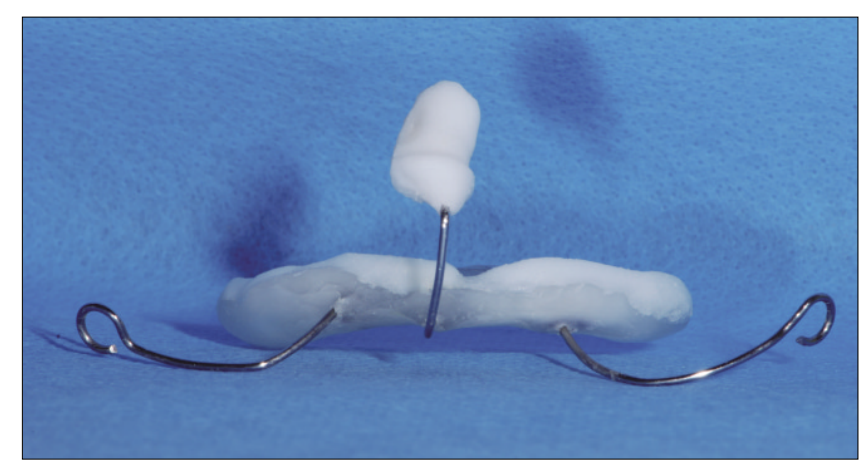

Fig. 1. K-NAM appliance.

aged between 10 to 37 days, were diagnosed with unilateral cleft lip and palate without any signs and symptoms of other syndromes.

Before fabricating the K-NAM appliance on the dental stone model, all undercuts were blocked out with wax. The plate was made with self-curing acrylic resin and orthodontic wire. The nasal arm and retention arm are made with wire for easier manipulation and smaller size of the appliance, thereby allowing the patient to close her lips with the appliance on. Tissue conditioner (COECOMFORT, GC America) was added on the tissue side of the appliance to prevent irritation of the soft tissue and as well as to increase retention(Fig. 1).

The appliance was delivered and maintained for about a week, for patient's adaptation. Afterward, tissue conditioner was added on the nasal wire area once every week for nasal molding and this process was done 5 to 8 times in total before the patient underwent a lip surgery.

The infant's nose was photographed from a basal view at the first visit, just before the lip surgery after nasal molding, and after the lip surgery. We consulted the study of Pai BC et al. ${ }^{11}$ to measure the effects of the appliance. The reference line was defined as the line connecting both alar bases.

The measurements included(Fig. 2);

Height of nostril : The highest point of the nostril perpendicular to the reference line in each nostril.

Width of nostril : The distance from the point farthest right to the point farthest left of the nostril on each side.

Angle of columella from cleft side: A line bisecting the columella was drawn from the tip of the nose to the reference line, and the angle was measured from the affected nostril. 


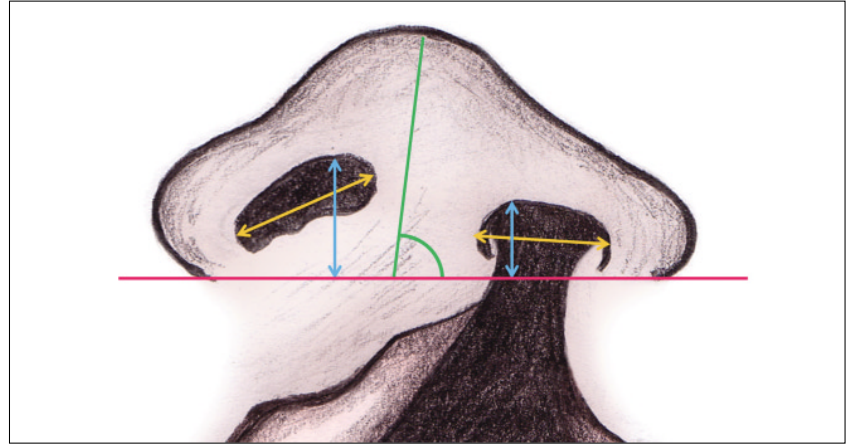

Fig. 2. Definitions of the measurements.

\section{Case I}

The first case is on a 37-day-old girl diagnosed as unilateral cleft on the left side. The appliance was delivered on the next day and nasal molding was conducted five times with an interval of one week. The lip surgery was done when she was 87 days old(Fig. 3).

The height ratio increased from 0.56 to 0.80 and the width ratio decreased from 1.87 to 1.57 . The columella angle increased from 68 degrees to 77 degrees (Table 1).

\section{Case II}

In order to minimize photographic errors, the measurements of height and width were calculated as a ratio of affected side to non-affected side. The nostrils, therefore, were considered more symmetric as the ratio approached a value of 1 .
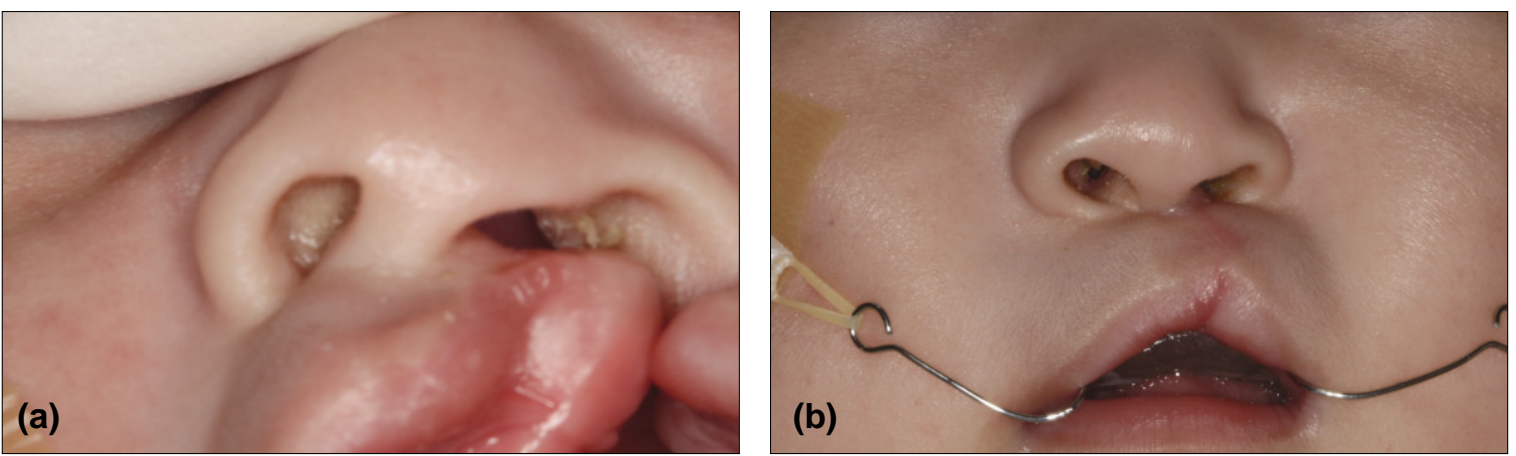

Fig. 3. The photographs of the first visit (a) and after the lip surgery (b) of case I.

Table 1. Changes in the measurements: Case I

\begin{tabular}{lccc}
\hline & First visit & After nasal molding & After cheiloplasty \\
\hline Height ratio & 0.56 & 0.80 & 0.75 \\
Width ratio & 1.87 & 1.57 & 0.76 \\
Columella angle & $68^{\circ}$ & $77^{\circ}$ & $86^{\circ}$ \\
\hline
\end{tabular}
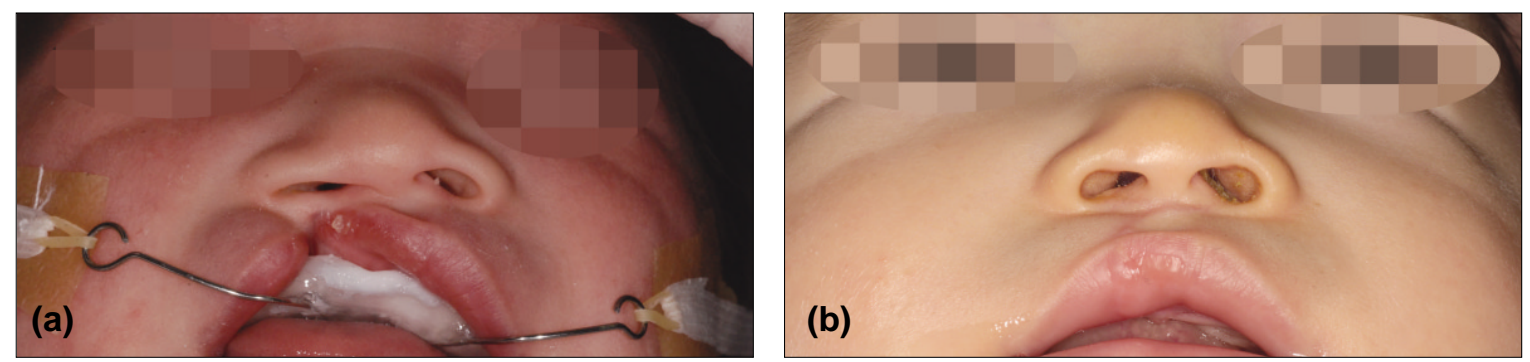

Fig. 4. The photographs of the first visit (a) and after the lip surgery (b) of case II. 
Table 2. Changes in the measurements: Case II

\begin{tabular}{lccc}
\hline & First visit & After nasal molding & After cheiloplasty \\
\hline Height ratio & 0.64 & 0.84 & 0.94 \\
Width ratio & 1.37 & 1.22 & 0.93 \\
Columella angle & $75^{\circ}$ & $79^{\circ}$ & $86^{\circ}$ \\
\hline
\end{tabular}

The height ratio increased from 0.64 to 0.84 , whereas the width ratio decreased from 1.37 to 1.22 . The angle increased from 75 degrees to 79 degrees(Table 2).

\section{Case III}

A girl visited our department for the first time when she was 19 days old. She was diagnosed as unilateral cleft lip and palate on the left side. The appliance was delivered 2 days later, and nasal molding was done 8 times every week. The lip surgery was done when she was 94 days old(Fig. 5).

The height ratio increased from 0.35 to 0.72 , whereas the width ratio decreased from 1.95 to 1.21 . The columella angle increased from 46 degrees to 68 degrees (Table 3).

\section{Discussion}

CLP are the most common maxillofacial deformities that cause many esthetic problems as well as functional disorders. Especially in unilateral CLP, the patient has a remarkably asymmetric nose resulting from the short- ened columella on the affected side. Many attempts have been made to resolve this problem and as a result of $\mathrm{ad}^{-}$ vanced surgical techniques combined with novel procedures such as nasoalveolar molding, the treatment result is ever since satisfactory.

Since McNeil first introduced the concept of modern presurgical infant orthopedics (PSIO) in 1950, there has been great advancement in presurgical infant orthopedic appliances. Furthermore, the study of Matuo and Hirose on the plasticity of cartilage in infants, resulting from the high level of hyaluronic acid, made presurgical nasoalveolar molding feasible. Afterward, several studies on the long-term effect of presurgical nasoalveolar molding confirmed its effect to enhance nasal symmetry ${ }^{12-14}$.

The newborns in these cases were referred from the department of Plastic Surgery, Kyungpook National University Hospital for nasal molding. Nasal molding was conducted using K-NAM appliance composed of acrylic resin plate and orthodontic wire.

The height and width of nostrils and the angle of col- $^{-}$ umella were measured and compared at the first visit, before the lip surgery after nasal molding, and after the lip surgery. In all cases, the noses of the newborns with
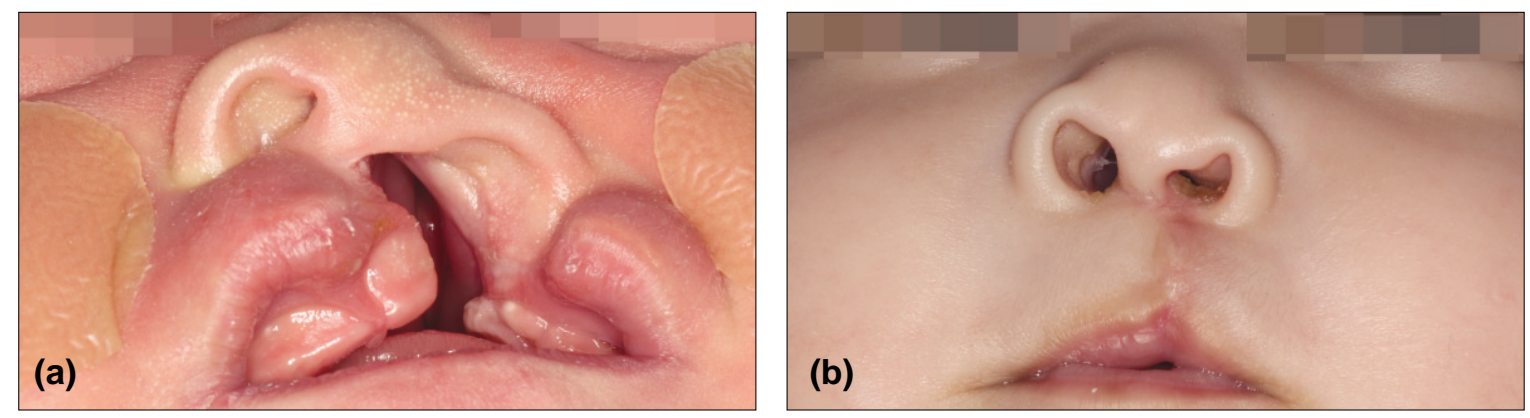

Fig. 5. The photographs of the first visit (a) and after the lip surgery (b) of case III.

Table 3. Changes in the measurements: Case III

\begin{tabular}{lccc}
\hline & First visit & After nasal molding & After cheiloplasty \\
\hline Height ratio & 0.35 & 0.72 & 0.75 \\
Width ratio & 1.95 & 1.21 & 0.94 \\
Angle & $46^{\circ}$ & $68^{\circ}$ & $92^{\circ}$ \\
\hline
\end{tabular}




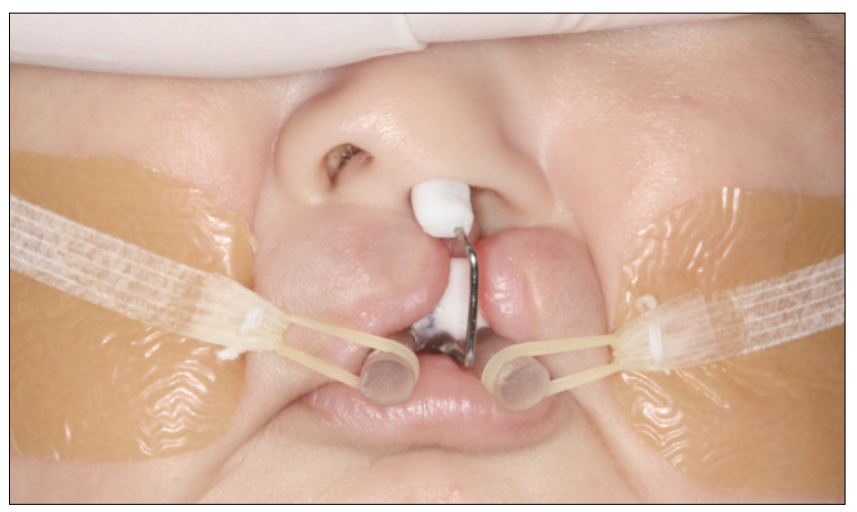

Fig. 6. Prototype K-NAM appliance.

unilateral CLP displayed obvious asymmetry in terms of width, height and columella angle at the first visit. Both after nasal molding and after the lip surgery the height and width of the nostrils demonstrated improved symmetry. The columella was deviated to the unaffected side at the initial visit, but became more upright after the lip surgery.

From the result of these cases, it is suggested that the K-NAM appliance may have effect on enhancing nasal symmetry in terms of height and width ratio of nostrils as well as columella angle.

Since nasal molding is feasible only for the limited period of 3-4 months after birth, it is critical to wear the appliance as long as possible during the confined time in order to achieve the optimal result.

As shown in Figure 6, the prototype K-NAM appliance had elastic bands directly attached to the resin retention arms extended from the plate. The patient was unable to close her lips and had trouble in feeding. To overcome this problem, the resin retention arms were replaced with orthodontic wire to enable the patients to suck by completely closing their lips. As a result, they could freely use a nursing bottle and wear the appliance all day. And, the nasal and alveolar molding effect was enhanced through the sucking action(Fig. 7).

Additionally, the manipulation of the appliance became easier by simply bending the wire and retention was also increased.

To obtain satisfactory results, the parents' and patient's cooperation is essential. With proper training and clinical experience, K-NAM appliance may have tremendous benefits for both the cleft patient and the surgeon.

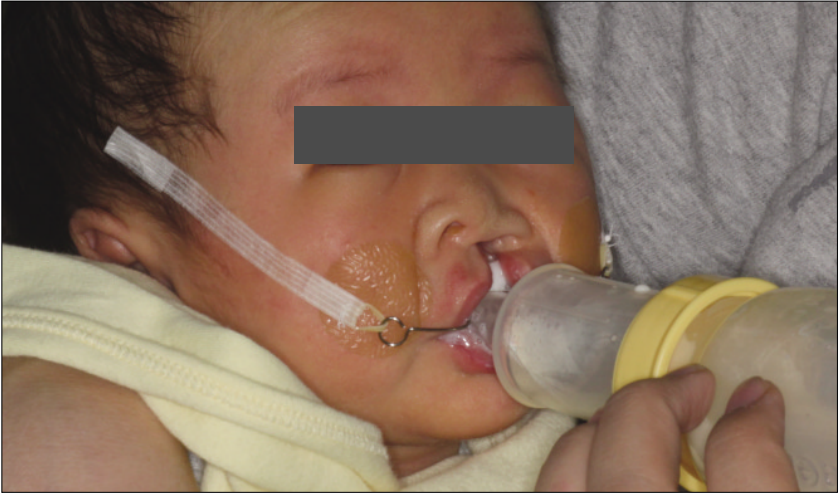

Fig. 7. Bottle-feeding with advanced K-NAM appliance on.

\section{Summary}

Since cleft lip and palate(CLP) are one of the most common craniofacial anomalies, many methods to treat CLP have been developed. However, surgical repair alone cannot resolve the nasal deformity and asymmetry. There have been many attempts for esthetic improvement including advanced techniques such as presurgical nasoalveolar molding(PNAM).

Three infants diagnosed with unilateral cleft lip and palate were referred from the department of Plastic Surgery to the department of Pediatric Dentistry, Kyungpook National University Hospital. The K-NAM appliances were installed and nasal molding was conducted 5 to 8 times before undergoing the lip surgery. The measurements of the height and width of nostrils and columella angle were compared at the pre-treatment, after nasal molding and after the lip surgery and improvement in the nasal symmetry was found in all three patients. The K-NAM appliance extends the wearing time within the limited period and is expected to maximize the treatment effects. When combined with parents' cooperation and a skilled practioner, the KNAM appliance would play a major role in enhancing nasal symmetry.

\section{References}

1. Dean, Avery, McDonald : Dentistry for the child and adolescent, MOSBY, 614.

2. Salyer KE. : Early and late treatment of unilateral cleft nasal deformity. Cleft Palate Craniofac J, 29:556-569, 1992

3. Dibbell DG. : Cleft lip nasal reconstruction: correct- 
ing the classic unilateral defect. Plast Reconstr Surg, 69:264-271, 1982.

4. McComb H. : Primary correction of unilateral cleft lip nasal deformity: a 10-year review. Plast Reconstr Surg, 75:791-799, 1985.

5. Matsuo K, Hirose T, Tomono T, et al. : Nonsurgical correction of congenital auricular deformities in early neonate: a preliminary report. Past Reconstr Surg, 73:38-51, 1984.

6. Matsuo K, Hirose T. : Preoperative nonsurgical over-correction of cleft lip nasal deformity. Br J Plast Surg, 44:5-11, 1991.

7. McNeil C. : Orthodontic procedures in the treatment of congenital cleft palate. Dent Record, 70:126-132, 1950.

8. Georgiade NG, Latham RA. : Maxillary arch alignment in the bilateral cleft lip and palate infant, using pinned coaxial screw appliance. Plast Reconstr Surg, 56:52-60, 1975.

9. Hotz M, Perko M, Gnoinski W. : Early orthopaedic stabilization of the premaxilla in complete bilateral cleft lip and palate in combination with the Celesnik lip repair. Scand J Plast Reconstr Surg Hand Surg, 21:45-51, 1987.
10. Grayson BH, Santiago PE, Brecht LE, Cutting CB. : Presurgical nasoalveolar molding in infants with cleft lip and palate. Cleft Palate Cranofac J, 36:486-498, 1999.

11. Pai BC, Ko EW, Huang CS, Liou EJ. : Symmetry of the nose after presurgical nasoalveolar molding in infants with unilateral cleft lip and palate: A preliminary study. Cleft Palate Craniofac J, 42: 658-663. 2005.

12. Bennun RD, Perandones C, Sepilarsky VA, et al. : Nonsurgical crorrection of nasal deformity in unilateral complete cleft lip: a 6-year follow-up. Plast Reconstr Surg, 194:616-630, 1999.

13. Grayson BH, Cutting CB. : Presurgical nasoalveolar orthopedic molding in primary correction of the nose, lip, and alveolus of infants born with unilateral and bilateral clefts. Cleft Palate Craniofac J, 38:193198, 2001.

14. Liou EJ, Subramanian M, Chen PK, Huang CS. : The progressive changes of nasal symmetry and growth after nasoalveolar molding: a three-year follow-up study. Plast Reconstr Surg, 114:858-864, 2004. 
국문초록

\title{
편측성 구순구개열 신생아에 대한 술전비치조정형장치의 효과
}

\author{
김진선 · 김영진 · 남순현 · 김현정 \\ 경북대학교 치의학전문대학원 소아치과학교실
}

구순구개열은 얼굴에 발생하는 다양한 종류의 기형 중 빈번히 발생하는 기형으로, 발생 빈도는 일반적으로 1000 명당 $0.28 \sim 3.74$ 명으로 알려져 있으나 파열의 종류, 인종 및 성별에 따라 큰 차이를 보인다.

구순구개열의 치료는 수술영역에서 많은 발전이 있었지만 수술만으로는 문제점을 해결하기는 어렵다. 파열부 간격을 줄이 고 구순열 수술을 용이하게 하기 위한 술전 신생아 정형술의 개념이 1950 년 $\mathrm{McNeil}$ 에 의해 개발되었으며, 최근에는 술전 비치조 정형장치 (presurgical nasoalveolar molding appliance, PNAM)를 사용하여 치조골뿐만 아니라 코의 모양을 정상 화하려는 시도가 이루어지고 있다.

세 명의 환자가 편측성 구순구개열로 진단받은 후 술전비치조정형장치 장착을 위해 의뢰되었다. 레진과 교정용와이어를 이 용하여 제작한 K-NAM 장치물을 입술 성형 수술을 시행하기 전까지 장착하였다. 첫 내원시와 nasal molding을 시행하여 입술 성형 수술을 하기 직전, 입술 성형 수술 이후 콧구멍의 높이, 너비, 비주의 각도를 측정하여 비교한 결과 세 증례에서 모 두 코의 대칭성이 증가하며 술 후 심미개선에 효과적임을 알 수 있었다. K-NAM 장치물은 장치의 장착, 유지, 조절이 용이 하고 장착한 상태에서 수유가 가능하기 때문에 장착시간을 증가시킬 수 있다. 따라서 nasal molding이 가능한 한정된 기간 안에 최대의 효과를 기대할 수 있다. 그리고 젖병을 빠는 행위가 가능해짐으로써 동시에 구강조직의 발달에도 도움을 줄 수 있을 것이라 생각한다.

주요어: 술전비치조정형술, 편측성 구순구개열 